\title{
PALEOCURRENT VARIABILITY IN MEANDERING AND BRAIDED RIVER SYSTEMS: MODERN CALIBRATION AND STRATIGRAPHIC CASE STUDIES SPANNING THE PALEOCENE-EOCENE THERMAL MAXIMUM
}

ANTHONY SEMERARO, Western Washington University

Research Advisor: Brady Z. Foreman

\section{INTRODUCTION}

Small width-to-depth ratios and sinuous single-thread channels characterize meandering river morphologies. Large width-to-depth ratios and relatively straight, multi-threaded channels characterize braided river morphologies. Meandering rivers typically form on shallow alluvial slopes with denser vegetation and fine-grained floodplains, which stabilizes the banks and allows the generation of sinuosity. Braided rivers generally form with wide shallow channels and high bedload transport in locations with low bank cohesion and variable discharge. The lack of bank cohesion, possibly from a lack of vegetation and clay content, destabilizes riverbanks, increasing the erosion of the banks, and preventing the formation of a large sinuous channel. Instead numerous smaller channels with migrating bars form throughout the river that subdivide the flow. Both river morphologies are common on modern day Earth, and are commonly identified in ancient stratigraphic sequences (Miall, 1985; Nichols, 2009). Criteria for distinguishing between these morphologies focus on grain size, in-channel lithofacies, channel morphology, fluvial sandbody geometry, and overbank lithofacies associations (Miall, 1985; Nichols, 2009). Here, I evaluate another proposed indicator that may be useful in determining paleo-channel morphodynamics. Both major river morphologies flow in a mean vector direction (i.e., down the steepest slope towards base level), but the individual channel flow measurements of a meandering river hypothetically should vary more greatly than braided rivers, simply as a consequence of the greater sinuosity exhibited by meandering rivers.

This is a particularly important problem in terms of Earth surface dynamics and the interpretation of sediment transport on other planetary surfaces. For example, there was no deep-rooted terrestrial vegetation present until the evolution of vascular plants with deep root systems in the late Devonian (Gibling and Davies, 2012). This change in terrestrial vegetation contributed to the evolution of fluvial system morphology (Gibling et al., 2013). During this shift, coal beds and other vegetation markers began to appear in the rock record. River deposits shifted from those indicative of mainly wide, sheet-like braided morphology to more isolated, lenticular geometries with well-developed point bar deposits (Davies, 2010). Researchers suggest that riverbanks with just 18-20\% roots by volume are approximately 20,000 times more stable than banks lacking vegetation root structures, which lead to the change (Davies, 2010). Moreover, these changes are also captured by small-scale, simplified flume experiments (Tal and Paola, 2007).

This research focuses on the main factors that differentiate meandering and braided rivers by creating a modern dataset to assess the morphologies of paleoriver data from which it is difficult to recover the planform morphology. Using Google Earth, a modern database of 6 rivers ( 3 meandering, 3 braided) was created to find the dispersion values (a measurement of variability) of channel directions of meandering and braided rivers. This study assesses if meandering and braided river morphologies can be found from 
paleocurrent data reliably and how many paleocurrent measurements need be taken in order to obtain reliable results. Furthermore, we apply our modern data sets to new and compiled paleocurrent measurements spanning the Paleocene-Eocene Thermal Maximum (PETM), an abrupt global warming event 56 million years ago, that corresponds to substantial changes in fluvial deposition in the Western Interior of the United States (Foreman et al., 2012; Foreman, 2014; Dechesne et al., in review).

\section{GEOLOGIC SETTING}

We focus on six modern river systems, identified below, that display end-member planform morphologies of meandering and braided configurations. Our stratigraphic data set is derived from three Laramide structural basins in the Western Interior of the United States. The new and compiled paleocurrent data are derived from the Piceance Creek Basin in northwest Colorado (Foreman et al., 2012), the Bighorn Basin in northwest Wyoming (Foreman, 2014), and the Hanna Basin of south-central Wyoming (Dechesne et al., in review; this study). All three basins within this study formed during the Laramide Orogeny between the Late Cretaceous and Paleogene, as thin-skinned deformation of the Sevier Orogeny gave way to thick-skinned deformation (Dickinson et al., 1988; Dickinson, 2004; Fig. 1). The region of North America wherein all three basins lay was part of a shallow interior sea until the uplift of the Laramide ranges (Wroblewski, 2003; Dickinson, 2004). The Laramide Orogeny caused basement-involved uplift of several ranges around each of the three basins of interest, which provided detritus to the adjacent basins. The paleocurrent records are derived from the fluvial units within these basins, and the paleocurrent measurements are divided into pre-, during, and postPETM stratigraphic bins.

The PETM was a global warming event that occurred approximately $56 \mathrm{Ma}$ and lasted for approximately 200 kyrs with a global temperature rise between $5^{\circ}$ and $8^{\circ} \mathrm{C}$ (McInerney and Wing. 2011). This climate change event was caused by a massive influx of approximately 4000 petagrams of carbon into the atmosphere potentially from a variety of sources (McInerney and Wing, 2011). The rapid increase in

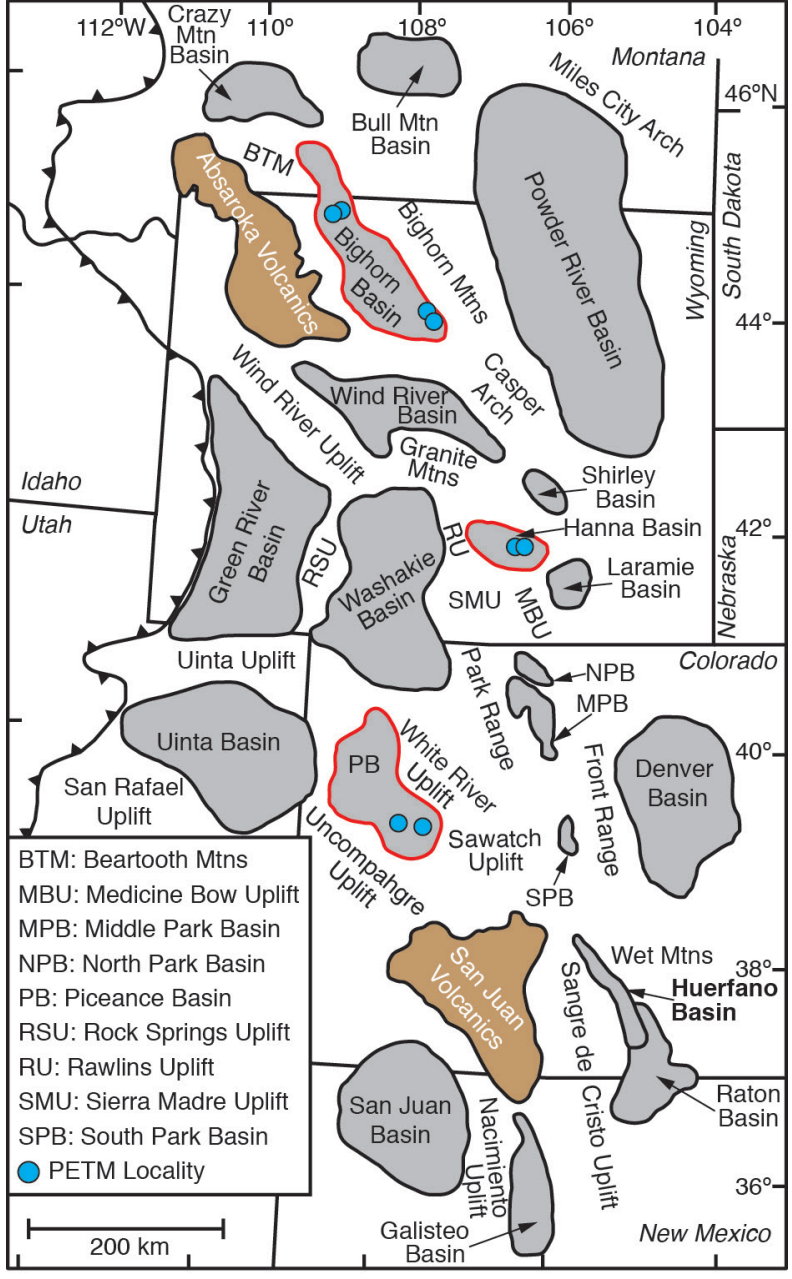

Figure 1. Map of the Western Interior of North America showing locations of Laramide basins that contain the PETM and paleocurrent measurements used in this study outlined in red.

temperature likely caused many terrestrial changes in vegetation, precipitation, and atmospheric circulation (McInerney and Wing, 2011; Carmichael et al., 2017). Rapid changes in temperature and precipitation regimes likely altered vegetation structure from denser, deciduous forests into sparser drier vegetation regimes dominated by legumes (Wing et al., 2005). After the PETM, vegetation quickly shifted back to near its pre-event condition. Additionally, there is evidence for decreases in mean annual precipitation and potentially increased discharge and sediment flux in Laramide basins (Wing et al., 2005; Kraus and Riggins, 2007; Foreman et al. 2012; Foreman, 2014). Fluvial stratigraphic responses include the deposition of thick, laterally continuous sandbodies, putatively related to changes in river morphodynamics during the PETM and potentially a transient shift in river planform morphology (Fig. 2). 


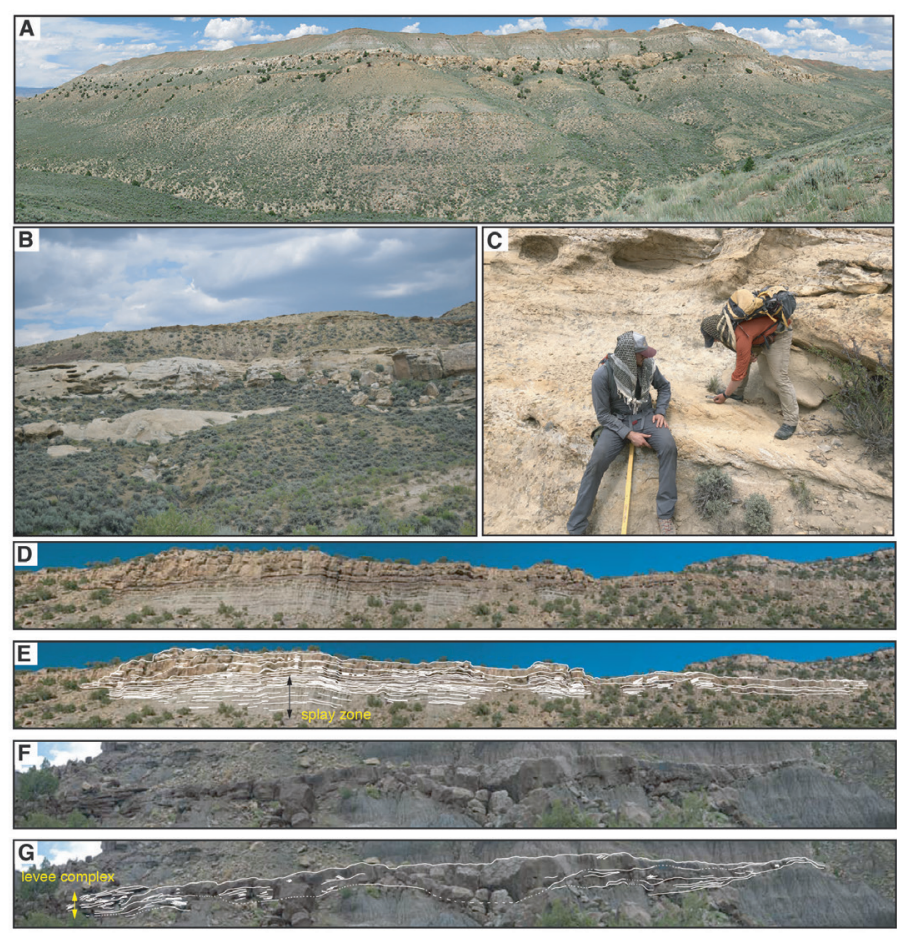

Figure 2. (A) Outcrop photo-mosaic of the Hanna Formation at one of the carbon isotope stratigraphic sections. Note the large fluvial sandbody, which is within the PETM. (B) Example of fluvial sandbody within the Eocene portion of the study area. (C) Photograph of large-scale cross-bedding being measured for paleocurrent. (D\&E) outcrop image of a fluvial sandbody in the Molina Member of the Wasatch Formation (northwest Colorado) interpreted as the result of a braided river system, and $(E \& F)$ outcrop image of a fluvial sandbody in the Atwell Gulch Member of the Wasatch Formation (northwest Colorado) interpreted as the result of a meandering river system.

\section{METHODOLOGY}

\section{Modern Data}

Google Earth was utilized to measure 1000 synthetic current measurements for 6 rivers ( 3 meandering, 3 braided) that were analyzed through directional statistics to calculate their dispersion values. The sections of each river that appeared the least affected by anthropogenic forces (dams, channels, canals, levees, etc.) were chosen. To calculate the dispersion value, first the polar coordinate directions are converted to Cartesian coordinates, the average $\mathrm{x}$ and $y$ coordinates are then squared, summed together, and the square root is taken to obtain the dispersion value. The higher the dispersion value, the more confined the spread of the data, whereas the lower the value, the more equally spread the data is. The original current measurements are plotted on rose diagrams to visually analyze the differences in river morphology as well as to find the mean vector of the data. To find how many current measurements are needed to get a reliable estimate of dispersion values, the original 1000 measurements were subsampled down to 5 measurements by randomly selecting $n$ measurements from the original 1000 using Monte Carlo methods to calculate the dispersion value 500 times to get an average dispersion value for each sample size (Figure 3). $95 \%$ confidence intervals are calculated for each sample size and are negligible until fewer than 25 measurements.

\section{Stratigraphic Data}

Paleocurrent data was measured from sedimentary structures in the sandbody outcrops including trough cross bedding, planar cross bedding, and climbing ripples in all three basins (DeCelles and Langf, 1983; Fig. 2). Paleocurrent measurements for Hanna Basin were taken directly for this study. Data from the Bighorn and Piceance basins were collected by Foreman (2014) and Foreman et al. (2012), respectively. Using these features in the outcrops, the flow directions were measured using a brunton compass (Figure 1c). In each basin, the outcrops were grouped into pre-PETM, PETM, and post-PETM to analyze how river morphology changed throughout the PETM. Bighorn Basin has 397 total paleocurrent measurements (95 pre-PETM, 139 PETM, 163 post-PETM), Piceance Creek Basin has 209 total measurements (74 pre-PETM, 59 PETM, 76 post-PETM), and Hanna Basin has 280 measurements (121 pre-PETM, 89 PETM, 70 postPETM). The measurements for each group were subsampled from 75 down to 5 measurements and the dispersion value was analyzed for them with the same directional statistics and Monte Carlo method as the modern datasets. The dispersion value remains constant above 40-50 current measurements of a river. Ancient datasets with fewer than 75 measurements were extrapolated to 75 measurements based upon the constant dispersion value at $>50$ measurements.

\section{RESULTS}

\section{Modern Data}

Modern river systems identified as meandering and braided show a clear separation between dispersion 


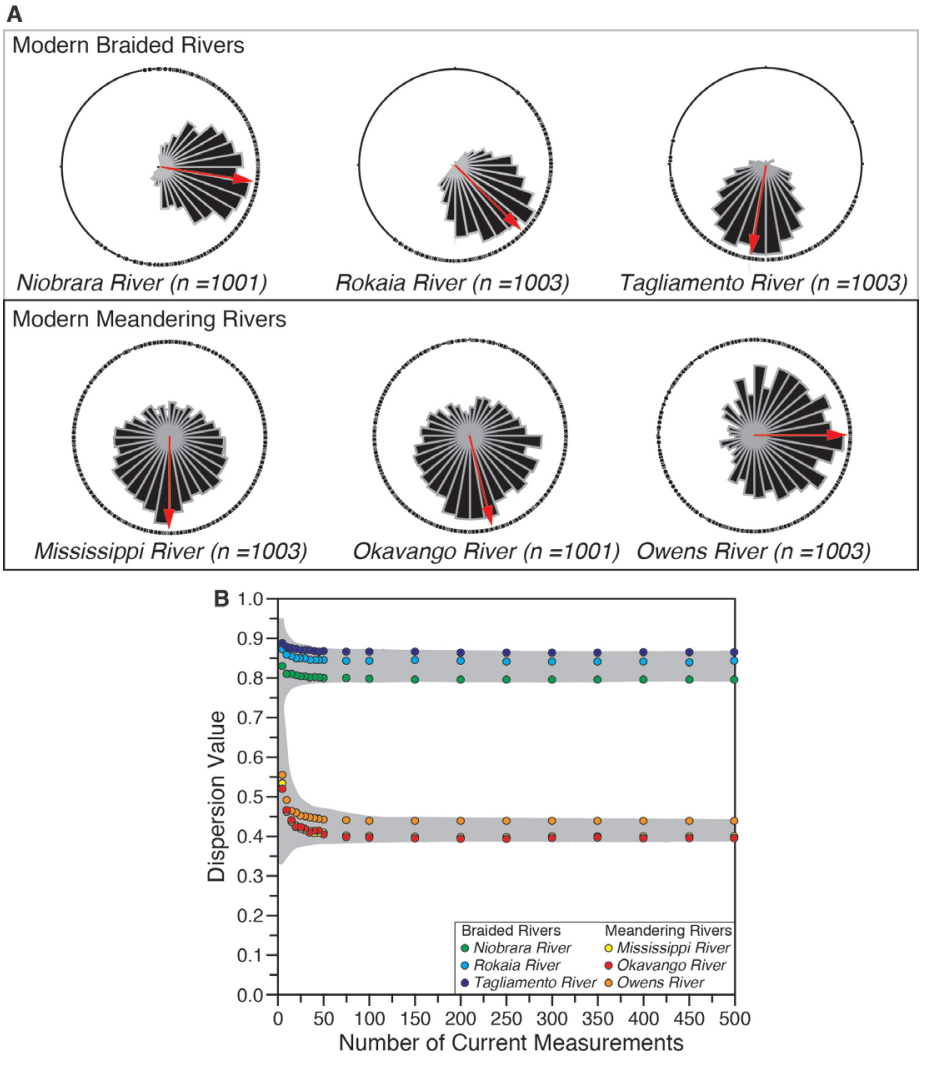

Figure 3. (A) Example of rose diagrams for modern meandering and braided river systems (n equal to the total number of measurements and the red arrow denotes the vector mean), and (B) dispersion values of current measurements at decreasing sample size (grey zone includes the values between the individual rivers analyzed and a 95\% confidence interval for each dispersion estimate determined by subsampling routine). Note only 25 current measurements are needed to distinguish meandering from braided dispersion values.

values for all paleocurrent measurements above $n=$ 25. Dispersion values for braided rivers ranged from 0.78 to 0.89 and values for meandering ranged from 0.39 to 0.55 (Figure 3 ). Braided rivers displayed a lack of measurements on their rose diagrams opposite of the mean vector, indicating that a majority of channels flow towards the mean vector direction downstream. In contrast meandering rivers display $360^{\circ}$ of paleoflow directions (Figure 3 ). The formation of many smaller channels in braided rivers increased the number of measurements over a similar distance, whereas meandering rivers with one channel can only provide a few measurements over a similar reach. Braided rivers in general have a majority of their current directions flowing close ( $<90$ degrees) to the main vector direction whereas meandering rivers contain current measurements that flow variably (up to and $>90$ degrees) in the opposite direction of the mean vector with flow directions encompassing every bracket angle on the rose diagram. The sinuosity of the meandering rivers yields greater spread in their paleoflow directions and a decreased dispersion value.

\section{Stratigraphic Data}

Paleo-river systems from each basin experienced similar shifts in dispersion values in relation to the PETM (Fig. 4 \& 5). Specifically, each basin displays an increase at the PETM, and then a decrease after the event. The range of dispersion values for each basin and time interval is conservatively estimated by the following methods. The first number in each range for each dataset is the dispersion value for $n>50$ measurements. The higher number in the range is the highest dispersion value each dataset reaches; this is for 5 measurements and the $95 \%$ confidence interval is too great to distinguish between river morphologies. The Bighorn Basin started with a range of 0.47 to 0.55 , with an increase to 0.75 to 0.79 during the PETM, with a decrease down to 0.56 to 0.66. The Hanna Basin experienced a very minor increase in dispersion value within the range 0.58 to 0.74. After the PETM, the dispersion value for the Hanna Basin decreased greatly to a range of 0.20 to 0.50. The Piceance Creek Basin started with values from the Atwell Gulch Member between 0.66 to 0.73 , increased to 0.74 to 0.78 within the Molina Member, and then dropped to 0.55 to 0.64 for the Shire Member (Figure 4,5). A majority of the data sets plot between the modern database braided and meandering values with one set from Hanna Basin plotting below the meandering database.

\section{DISCUSSION AND CONCLUSIONS}

Our modern datasets suggest that river systems with different planform morphologies will produce different paleocurrent patterns. Braided rivers have wide and shallow channels with numerous bars within the channels whereas meandering rivers consist of one sinuous deep channel with lateral migration and deposition. Braided morphologies generally tend to flow in one direction with all channels within the river flowing towards the mean vector direction of the river. Meandering morphologies with their sinuous channels can flow in almost any direction relative to the mean 

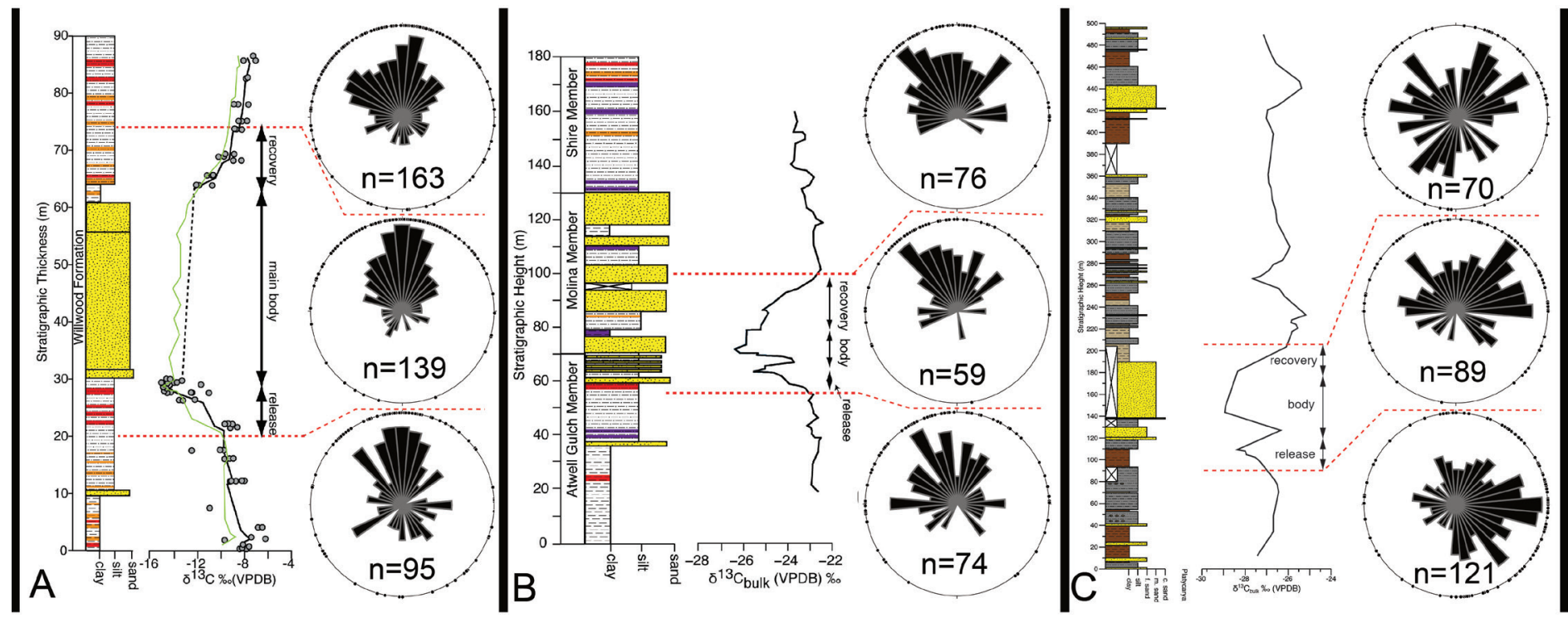

Figure 4. Stratigraphic sections and carbon isotope stratigraphies in (A) Bighorn Basin, (B) Piceance Basin, (C) Hanna Basin. Each of the basins studied herein showing up-section changes in paleodrainage before (bottom), during (middle), and after the PETM (top). Data from Bowen et al. (2001), Foreman et al. (2012), Foreman (2014), Chisholm (2019), and this study.

vector direction of the river. The modern data suggest that using this difference in flow directions and enough measurements (i.e., $n>25$ ), the morphology of an ancient river can be found using directional statistics, as meandering rivers will have a greater spread of flow directions (lower dispersion value) and braided rivers will have a more narrow spread (higher dispersion value). Additional rivers should be included in future work to evaluate if the distinction between meandering and braided rivers holds. Moreover, the sinuosity of the river systems should be calculated to explicitly tie the dispersion of current measurements with channel morphology. The observation that the ancient data sets largely fall in between modern dispersion values could have a number of causes. First, the modern data set may not have captured the full range of meandering and braided dispersion values exhibited by modern river systems. Second, the ancient datasets pool multiple river channel deposits over relatively large stratigraphic intervals together, which means different channel morphologies might have been artificially mixed, yielding intermediate dispersion values. Lastly, this might be due to time-averaging of paleocurrent directions within the stratigraphic datasets. Each fluvial sandbody represents the net depositional evolution of a river channel while it inhabited a particular position on the floodplain, potentially representing several hundreds to thousands of years. In contrast, the modern datasets are a snapshot of river morphology.

Paleocurrent measurements from the Bighorn Basin fall within the meandering river dispersion values for pre-PETM measurements, and then change to a braided river dispersion value during the PETM, and a trend returning towards meandering planforms again after the end of the PETM. The paleocurrent measurements from the Piceance Creek Basin and Hanna Basin do not directly fit within either braided rivers or meandering rivers dispersion values, as they may be transitioning from one morphology to the other and have a mixed morphology. In the Hanna Basin, the change in river planform is almost negligible from before the PETM to the PETM event meaning that there was only a slight shift in morphology in the Hanna Basin until a sharp decrease in dispersion value after the PETM. In the Piceance Creek Basin, there are large changes in dispersion value for prePETM, PETM, and post-PETM, but for each series of measurements, the dispersion values do not match either modern morphology. Transition periods when climatic forcings are changing could result in the slow transition from one planform to another in a fluvial system, rendering each individual sand body analyzed with a different planform that prevents the data from representing one definite planform and instead a mix of planforms that do not line up with either meandering and or braided morphology. 

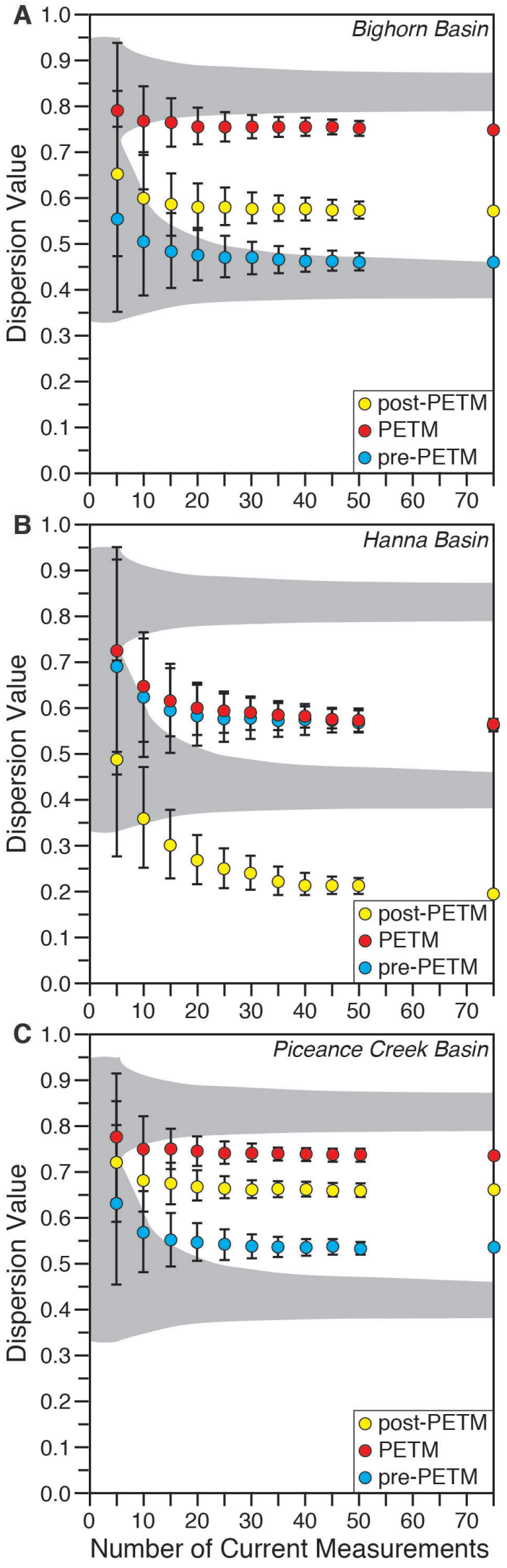

Figure 5. Plot of dispersion values of the Early Paleogene paleocurrent measurements for (A) Bighorn Basin, (B) Hanna Basin, and (C) Piceance Creek Basin. Grey zone is the meandering and braided dispersion value fields defined by modern river analyses.
The ancient river systems that did not fit into either definite morphology could have a mixed morphology such as an island-braided morphology or have a different morphology than modern rivers due to the lack of anthropogenic changes such as deforestation and levee/dam construction (Gibling and Davies, 2012). As precipitation, vegetation, and numerous other factors affect the requirements to fully transition a river from one planform to another (Bertoldi et al., 2009), if only one or two factors change, then the river could adopt a mixed planform forcing the dispersion value to not match a well-defined modern morphology. Previous studies have suggested that rivers became more braided and mobile during the PETM in a number of alluvial basins (Schmitz \& Pujalte, 2007; Foreman et al., 2012; Foreman 2014; Dechense et al., in review) and more efficient transport of sediment. Both factors could have reduced sinuosity and altered dispersion values. These changes in river morphodynamics appear to be related to an increase in the seasonality of precipitation and reduction in vegetation density in the floodplains (Wing et al., 2005; Kraus and Riggins, 2007; Foreman et al., 2012; Foreman, 2014; Carmichael et al., 2017). However, the paleocurrent analysis presented herein suggests it may not be a clear-cut case of a transition from purely meandering river systems to braided river systems and back again.

\section{ACKNOWLEDGEMENTS}

This material is based upon work supported by the Keck Geology Consortium and the National Science Foundation under Grant No. 1659322, as well as NSF grant EAR 145031 to Ellen Currano. I would like to show my appreciation for guidance through this project from Brady Foreman and Ellen Currano as well as Marieke Dechesne and Regan Dunn. Additional thanks to my Keck student collaborators Xavier Noguiera, Christine Shonnard, Keifer Nace, Jake Polsak, and James Chisholm.

\section{REFERENCES}

Bertoldi, W., Zanoni, L., Tubino, M. 2009. Planform Dynamics of Braided Streams. Earth Surface Processes and Landforms 34(4): 547-557. 
Carmichael, M., J., Inglis, G.N., Badger, M.P.S., Naafs, B.D.A., Behrooz, L., Remmelzwaal, S., Monteiro, F.M., Rohrssen, M., Farnsworth, A., Buss, H.L., Dickson, A.J., Valdes, P.J., Lunt, D.J., Pancost, R.D. 2017. Hydrological and associated biogeochemical consequences of rapid global warming during the Paleocene-Eocene Thermal Maximum. Global and Planetary Change 157: 114-138.

Corenblit, D., Tabacchi, E., Steiger, J., Gurnell, A.M. 2007. Reciprocal Interactions and Adjustments between Fluvial Landforms and Vegetation Dynamics in River Corridors: A Review of Complementary Approaches. Earth-Science Reviews 84(1-2): 56-86.

Davies, N. S., Gibling, M. R. 2010. Cambrian to Devonian Evolution of Alluvial Systems: The Sedimentological Impact of the Earliest Land Plants. Earth-Science Reviews 98(3-4): 171-200.

DeCelles, P.G., Langf, R.P. 1983. Two New Methods of Paleocurrent Determination from Trough Cross-Stratification. Journal of Sedimentary Research 53: 629-642.

Dechesne, M., Currano, E.D., Dunn, R.E., Higgins, P., Hartman, J.H., Chamberlain, K.R., HolmDenoma, C.S. in review, Geosphere. Depositional patterns of the fluvial to paludal strata of the Hanna Formation across the Paleocene-Eocene boundary, Hanna Basin, Wyoming.

Foreman, B. Z. 2014. Climate-Driven Generation of a Fluvial Sheet Sand Body at the Paleocene-Eocene Boundary in North-West Wyoming (USA). Basin Research 26(2): 225-241.

Foreman, B. Z., Heller, P.L., Clementz, M.T. 2012. Fluvial Response to Abrupt Global Warming at the Palaeocene/Eocene Boundary. Nature 491: 92-95.

Gibling, M.R., Davies, N.S., Falcon-Lang, H.J., Bashforth, A.R., DiMichele, W.A., Rygel, M.C., Ielpi, A. 2014. Palaeozoic Co-Evolution of Rivers and Vegetation: a Synthesis of Current Knowledge. Proceedings of the Geologists'
Association 125(5-6): 524-533.

Hajek, E. A., Heller, P.L., Schur, E.L. 2012. Field Test of Autogenic Control on Alluvial Stratigraphy (Ferris Formation, Upper Cretaceous-Paleogene, Wyoming). Geological Society of America Bulletin 124(11-12): 1898-1912.

Kraus, M.J., Riggins, S. 2007. Transient drying during the Paleocene-Eocene Thermal Maximum (PETM): Analysis of paleosols in the Bighorn Basin, Wyoming. Palaeogeography, Palaeoclimatology, Palaeoecology 245(3-4): 444461.

Kraus, M.J., Woody, D.T., Smith, J.J., Dukic, V. 2015. Alluvial Response to the Paleocene-Eocene Thermal Maximum Climatic Event, Polecat Bench, Wyoming (U.S.A.). Palaeogeography, Palaeoclimatology, Palaeoecology 435: 177-192.

McInerney, F.A., Wing, S.L. 2011. The PaleoceneEocene Thermal Maximum: A Perturbation of Carbon Cycle, Climate, and Biosphere with Implications for the Future. Annual Review of Earth and Planetary Sciences 39(1): 489-516.

Miall, A.D. 1985. Architectural-Element Analysis: A new method of facies analysis applied to fluvial deposits. Earth Science Reviews 22: 261-308.

Nichols, G. 2009. Sedimentology and Stratigraphy, 2nd Edition: West Sussex, United Kingdom, Wiley-Blackwell, $432 \mathrm{p}$.

Schmitz, B., Pujalte, V. 2007. Abrupt increase in seasonal extreme precipitation at the Paleocene-Eocene boundary. Geology 35: 215218.

Tal, M., Paola, C. 2007. Dynamic single-thread channels maintained by the interaction of flow and vegetation. Geology 35: 347-.350.

Wing, S. L., Currano, E.D. 2013. Plant Response to a Global Greenhouse Event 56 Million Years Ago. American Journal of Botany 100(7): 1234-1254.

Wing, S.L., Harrington, G.J., Smith, F.A., Bloch, J.I., Boyer, D.M., Freeman, K.H. 2005. Transient 
floral change and rapid global warming at the Paleocene-Eocene boundary. Science 310(5750): 993-996.

Wroblewski, A. 2002. The Role of the Hanna Basin in Revised Paleogeographic Reconstructions of the Western Interior Sea During the CretaceousTertiary Transition. Wyoming Geological Association Guidebook. 2002 Field Conference, p. $17-40$. 